Estudios Geológicos, 65(1)

enero-junio 2009, 49-65

ISSN: $0367-0449$

doi:10.3989/egeol.08642.036

\title{
GIS-based landslide susceptibility mapping models applied to natural and urban planning in Trikala, Central Greece
}

\author{
Mapas de susceptibilidad de deslizamientos basados en GIS \\ aplicados a la planificación natural y urbanística en Trikala, \\ Grecia Central
}

\author{
G.D. Bathrellos ${ }^{1}$, D.P. Kalivas ${ }^{2}$, H.D. Skilodimou ${ }^{1}$
}

\begin{abstract}
Landslide susceptibility mapping is a practical tool in natural and urban planning; it can be applied for determining land use zones, in construction design and planning of a variety of projects.

In this study, two different GIS based landslide susceptibility maps were generated in the mountainous part of the Trikala Prefecture in Thessaly, Central Greece. This was accomplished by using different methods for correlating factors, which have an effect on landslide occurrences. The instability factors taken into account were: lithology, tectonic features, slope gradients, road network, drainage network, land use and rainfall. A frequency distribution of the half number of the landslide events of the study area in each class of the instability factors was performed in order to rate the classes. Two models have been used to combine the instability factors and assess the overall landslide susceptibility, namely: the Weight Factor Model (WeF), which is a statistical method, and the Multiple Factor Model (MuF) that is a logical method. The produced maps were classified into four zones: Low, Moderate, High and Very High susceptible zones and validated using the other half number of the landslide events of the area. Evaluation of the results is optimized through a Landslide Models Indicator (La.M.I.).
\end{abstract}

Key words: Landslide susceptibility models, Maps, GIS, spatial planning, Central Greece.

\begin{abstract}
RESUMEN
Los mapas de susceptibilidad de deslizamientos representan una práctica herramienta en la planificación urbana y de espacios naturales. Así, puede aplicarse a la determinación de los usos de terrenos, en el diseño de construcción civil y para la planificación de gran variedad de actividades.

En este estudio se generaron dos tipos diferentes de mapas de susceptibilidad basados en GIS para la parte montañosa de la prefectura de Trikala en Tesalia (Grecia Central). Estos se llevaron a cabo usando dos métodos de correlación de los factores que pueden tener un efecto en la generación de deslizamientos. Los factores de desestabilización tenidos en cuenta fueron: litología, aspectos tectónicos, pendiente, red de carreteras, red de drenaje, uso de la tierra y pluviometría. La distribución de frecuencias de la media de eventos de deslizamiento en cada clase de factores de desestabilización, fue utilizada para clasificar cada una de dichas clases. Para combinar los factores de desestabilización y estimar la susceptibilidad a la generación de deslizamientos, se usaron dos tipos de modelos: el Weight Factor Model (WeF), basado en estimaciones estadísticas, y el Multiple Factor Model (MuF) basado en operadores lógicos. Los mapas producidos se dividieron en cuatro zonas en función de su grado de susceptibilidad: Bajo, Moderado, Alto y Muy Alto. Su validez se ponderó a partir de los valores medios de deslizamientos detectados en cada zona. Se propone que la evaluación de cada modelo se puede optimizar mediante la aplicación de un factor denominado Indicador de Modelos de Deslizamientos (Landslide Models Indicator, La.M.I.).
\end{abstract}

Palabras clave: Modelos de susceptibilidad de deslizamientos, mapas, GIS, planificación espacial, Grecia Central.

\footnotetext{
1 Department of Geography \& Climatology, Faculty of Geology \& Geoenvironment, National \& Kapodistrian University of Athens, University Campus, Zografou, 15784 Athens, Greece. Email: gbathellos@geol.uoa.gr

2 Department of Natural Resources Management \& Agricultural Engineering, Soil Science Laboratory, Agricultural University of Athens, 11855 Athens, Greece. Email: kalivas@aua.gr
} 


\section{Introduction}

Landslide is a major and common natural hazard. In Greece, natural disasters such as earthquakes, floods, and especially landslides, are widespread having sizable impact on rural (or national) economy. The bulk of landslide phenomena occur in the Western and Central part of the country, peaking along the Pindos mountain range axis, inflicting occasionally significant damages upon settlements and road networks (Rozos et al., 1988; Ziourkas \& Koukis, 1992).

Landslide hazard assessment is an important parameter for prediction and management of natural disasters; it is also a necessary step for natural and urban planning in government policies worldwide (Lekkas, 2000; Carrara et al., 2003).

During the recent decades, the use of landslide susceptibility and hazard maps for land use planning has drastically increased. The aim of these maps is to rank different sections of land surface according to the degree of actual or potential landslide hazard. Thus, planners are capable of selecting favorable sites for urban and rural development to prevent landslide hazards. The reliability of those maps depends mostly on the applied methodology as well as the available data used for the hazard risk estimation (Parise, 2001).

In the last twenty years, Geographical Information Systems (GIS) and Remote Sensing have become integral tools for the evaluation of natural hazard phenomena (Nagarajan et al., 1998; Liu et al., 2004). Moreover, GIS is an excellent and useful tool for the spatial analysis of a multi-dimensional phenomenon such as landslides, and for landslide susceptibility mapping (Carrara et al., 1999; van Westen et al., 1999; Lan et al., 2004).

There are various GIS based methods and techniques, which help to generate a landslide susceptibility map. Many researchers have separated these methods into direct geomorphological mapping, landslides inventory mapping, heuristic, statistical, and deterministic approaches (van Westen et al., 1999; Guzzetti et al., 1999).

Landslide events are based on various physical factors. Therefore almost all methods of landslide susceptibility mapping focus on: $a$ ) the determination of the physical factors which are directly or indirectly correlated with slope instability (instability factors); $b$ ) the selection of the rate-weighting system of all instability factors and of the individual classes of values of each factor; c) the overall estimation of the relative role of causative factors in producing landslides; and $d$ ) the final susceptibility zoning by classifying the land surface according to different hazard degrees (Anbalagan, 1992; Guzzetti et al., 1999; Dai et al., 2002).

Regarding the identification of the instability factors, the used data are in some cases either readily available or can be easily collected. In other cases statistical analysis was performed. As for the assigned rates and weights, the methodology used involves landslide inventory and frequency distribution, frequency ratio, density, multivariate statistical methods, trial and error method, local experience, field knowledge and literature (Gupta \& Joshi, 1990; Anbalagan, 1992; Zêzere et al., 1999; Temesgen et al., 2001; Lee \& Min, 2001; Donati \& Turrini 2002; Saha et al., 2002; Gritzner et al., 2001; Liu et al., 2004; Lee \& Sambath, 2006). Most of the methods employed for the overall estimation of the relative contribution of instability factors are based on mathematical operations, which combine the factors (Temesgen et al., 2001; Saha et al., 2002; Chau et al., 2004; Ayalew et al., 2005).

The goals of this study are: $a$ ) the production of landslide susceptibility maps based on GIS techniques using two different models of combining the instability factors and estimation of overall landslide susceptibility and $b$ ) the evaluation of these models and the produced maps.

\section{Study area}

The study area (fig. 1) is defined by the mountainous part of the Trikala prefecture and is located at Western Thessaly in Central Greece. It covers $1,631.21 \mathrm{~km}^{2}$ with altitudes varying from 200 to 2,204 $\mathrm{m}$ above sea level. The southern mountain range of Pindos, as well as the mountains of Koziakas, Hasia and Antihasia form the higher of the area. The upper stream of the Pinios River flows through the study area; the drainage network is well developed with a significant surface run off.

The geological structure of the area comprises pre-alpine, alpine and post alpine formations. The pre-Alpine formations are the metamorphic rocks of the Pelagonian Zone. The Alpine formations belong to four main stratigraphic zones, which are the Pindos Zone, the Koziakas Zone, the Sub-Pelagonian Zone, and the Pelagonian Zone. The post-Alpine formations from the older to the more recent are: Eocene to Miocene molassic formations of the Mesohellenic trench, Neogene sediments and Qua- 


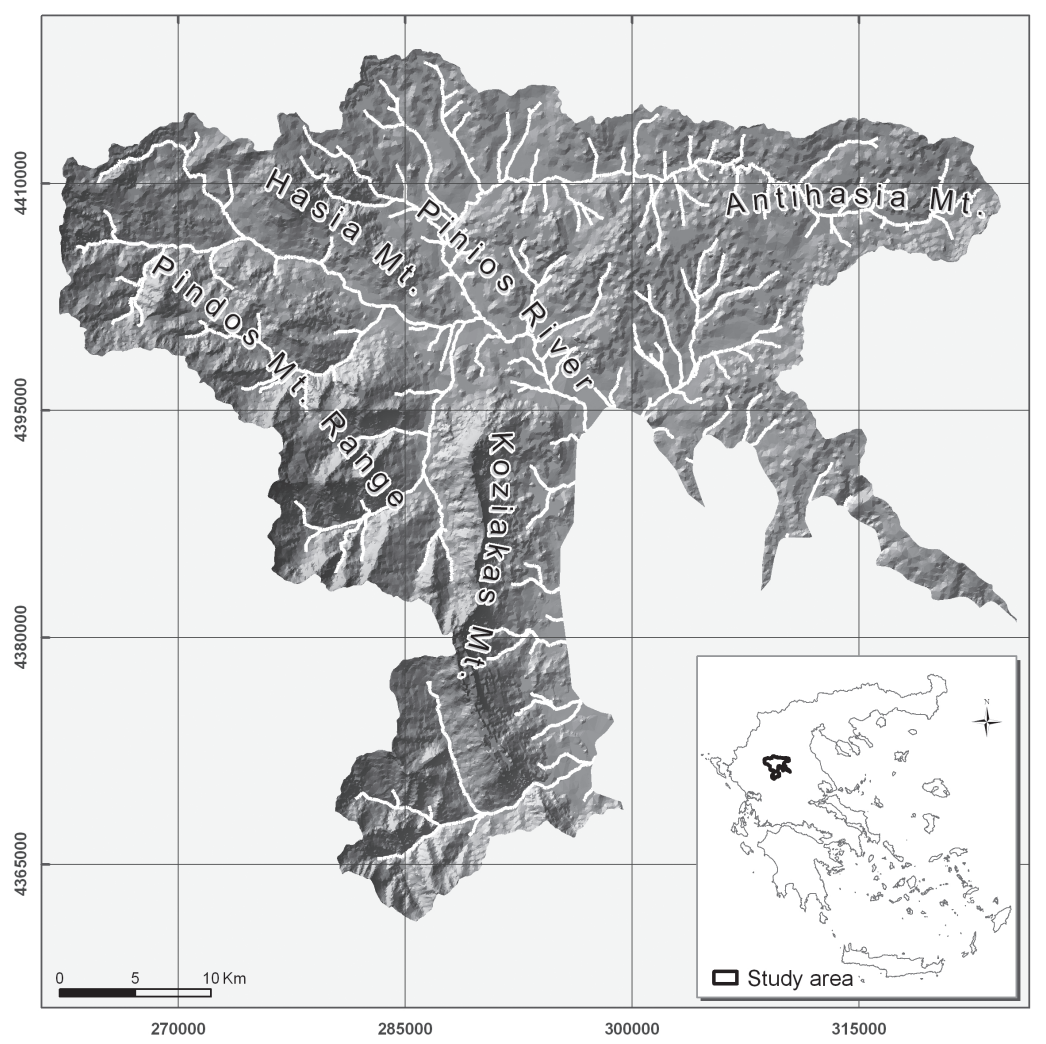

Fig. 1.-Location map, Digital Elevation Model (from contours, interval $20 \mathrm{~m}$ ) and drainage network of the study area.

ternary deposits, which cover the beds of rivers and streams (Bathrellos, 2005).

The climate is Mediterranean with a rainy period that begins in October and ends in May.

\section{Data sources}

This study was carried out using the following sources of information:

- Ten sheets of topographic maps $(1: 50,000$ scale) from the Hellenic Military Geographical Service (HAGS).

- The geological map of the study area (1:100,000 scale) (Bathrellos, 2005).

- The photo-lineaments map of the study area (1:100,000 scale) (Bathrellos, 2005).

- Rainfall data. Mean annual precipitation values for the years 1973-2003 from ten meteorological stations, courtesy of the Hellenic National Meteorological Service, the Ministry of Environment Planning and Public Works and the Ministry of Agriculture.
- Fieldwork. Extended field investigation was carried out during the years 2004 and 2005.

\section{Methodology}

\section{GIS database}

A GIS database has been developed using ArcGIS ver. 9.1 software. The landslide occurrences in the study area and the instability factors have been recorded and saved as separate layers in the database. All the data layers were in vector format, transformed in grids with cell size $20 \times 20$ meters.

\section{Landslide inventory map}

The landslide inventory map compilation has involved the following steps: $a$ ) the locations indicating landslide events were recognized on topographic maps and airphotos; $b$ ) landslide indications 
were verified by field work; and $c$ ) the manifested landslides were mapped on topographic sheets. The landslide occurrences were digitized as point layer.

It is important to mention that many of landslides express relatively old events and because of this it was very difficult to collect data for them and define their triggering factors. However according Rozos et al. (1988) in many cases heavy rainfall triggers landslides. The landslide events mapped in the study area comprise slides and flows, while the rock falls were not included. The landslide inventory map simply represents the spatial distribution of landslides without a subdivision into different types of mass movements.

The total number of landslide events in the study area was divided randomly into two groups with the same number of landslides, using the Geostatistical Analyst extension of ArcGIS. The first group was used for the investigation of the relation between the landslide occurrences and the instability factors and the second one for validation. The first group in the statistical analysis represents the training set of data, while the second one represents the testing set.

\section{Instability factors}

The instability factors which were taken into account for the creation of the landslide susceptibility map have been based on the literature (Gupta \& Joshi, 1990; Anbalagan, 1992; Koukis et al., 1997; Larsen \& Parks, 1997; Guzzetti et al., 1999; Zêzere et al., 1999; Dai \& Lee, 2001; Lee \& Min, 2001; Shaban et al., 2001; Temesgen et al., 2001; Saha et al., 2002; Donati \& Turrini, 2002; Lan et al., 2004; Liu et al., 2004; Guthrie \& Evans, 2004; Ayalew \& Yamagishi, 2005; Duman et al., 2005; Moreiras, 2005; Remondo et al., 2005). The factors are lithology, tectonic features, slope angle, road network, drainage network, land use and rainfall.

A lithological map (fig. 2) of the study area was generated based on the existing geological map (scale 1:100,000) (Bathrellos, 2005) and field geological observations. The lithological formations were digitized and saved in the GIS database as polygon layer.

Tectonic activity, either as mass movements (e.g. napes, thrusts) or as local movements (e.g. faults, folds, fissures), increases landslide events by creating steep slopes and sheared, weakened rocks. The tectonic features of the study area, observed in geo- logical and lineament maps, involve thrusts, overthrusts and faults (fig. 3). These features are inserted in the GIS database as line layer, while aiming at the investigation of the influence of the distance from tectonic features in landslides distribution, a tectonic buffer map was produced. Buffer zones were created around each thrust, overthrust and fault in such a distance that buffers included all the landslide events. Forty-five buffer zones were made with an interval of $100 \mathrm{~m}$ distance.

Contours with $20 \mathrm{~m}$ intervals and height points were digitized from topographic sheets (scale 1:50,000) and saved as line and point layer correspondingly. A Digital Elevation Model (DEM) was derived from the digitized elevation data using the 3D Analyst extension of ArcGIS, and the slope layer (fig. 4) was extracted from the DEM.

The road network of the study area was digitized and saved as a line layer in the GIS database, using the topographic sheets as data source. Similar to the case of tectonic features, twenty-four buffer zones were constructed around roads varying from 100 to $2,400 \mathrm{~m}$ in length.

The drainage network (fig. 5) of the study area was digitized from the topographic sheets (scale 1:50,000), and saved as line layer. We did not use the Spatial Analyst capabilities for the estimation of the drainage network since topography data are more reliable. Additionally, it was automatically classified by the Strahler method using ArcGIS capabilities. More specifically, the third and higher order streams were used in the context of this study, considering that high order streams may cause more serious problems of erosion and undercutting. Buffer zones were generated around each stream for the purpose of landslide hazard analysis. As in the cases of tectonic features and road network, buffer zones were built with an $100 \mathrm{~m}$ interval at a distance up to $1,900 \mathrm{~m}$.

The land use of the study area was taken from the CORINE Land Cover Program. The program contains land cover data for Europe including land cover class description at scale 1:100,000 published by the European Commission (Bossard et al., 2000). The CORINE land use map was classified as follows: forest areas, transitional woodland/shrub, shrubby areas, natural grassland with trees and shrubs, natural grassland, agricultural areas, settlements and barren areas (fig. 6). The land use of the area was saved as polygon layer.

The study area was divided into ten areas in relation to mean annual precipitation from the present 


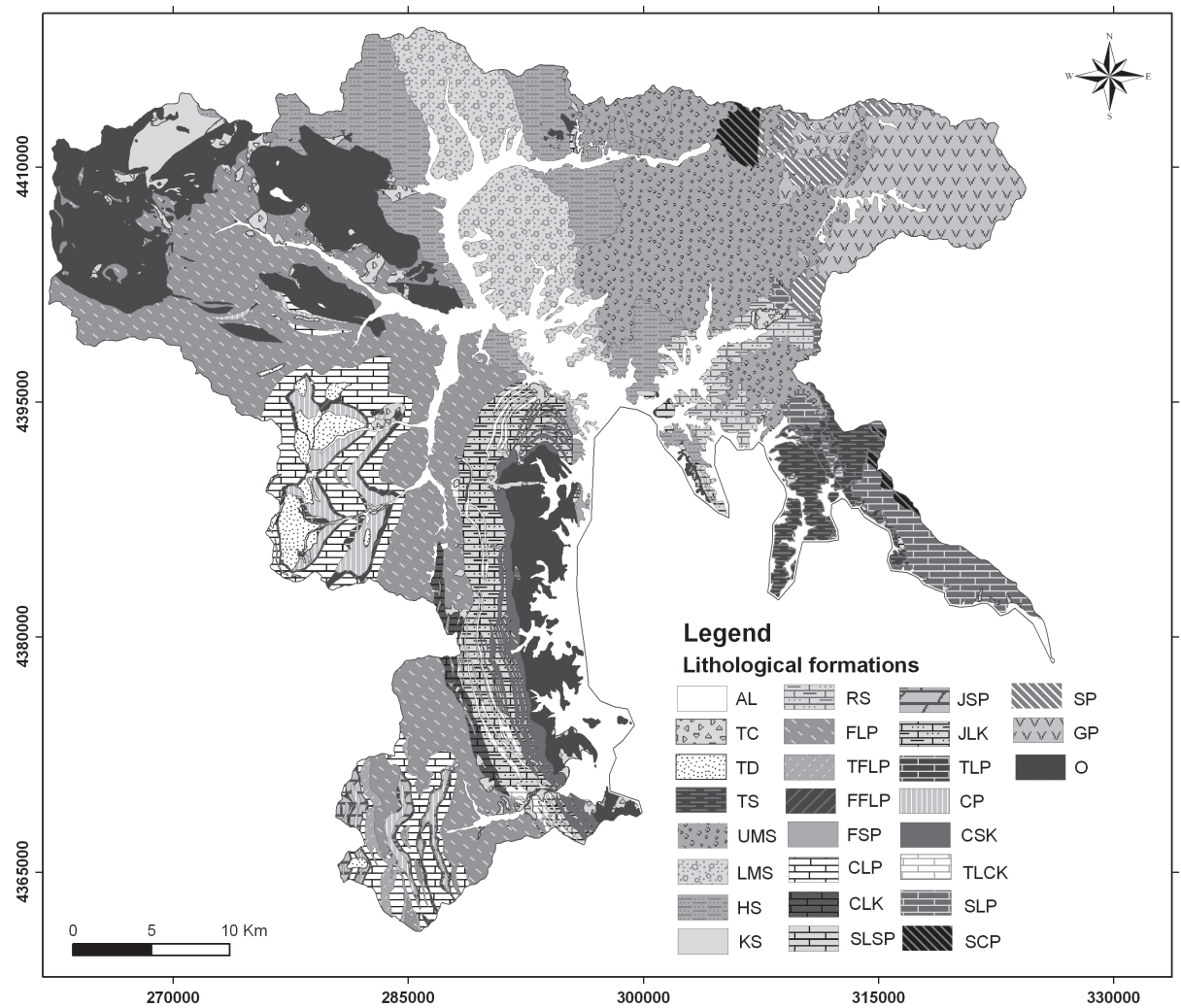

Fig. 2.-Lithologic map of the area. $\mathrm{AL}=$ Alluvial deposits, $\mathrm{TC}=$ Talus cones and scree, $\mathrm{TD}=$ Terrestrial deposits, $\mathrm{TS}=\mathrm{Trikala}$ series, UMS = Upper Meteora Series, LMS = Lower Meteora Series, HS = Clastic formations of Heptachorion-Kipourion Series, $\mathrm{KS}=$ Clastic formations of Krania Series, RS = Clastic formations and limestones of Rizoma Series, FLP = Flysch of Pindos Zone, TFLP $=$ Transition beds of Flysch of Pindos Zone, FFLP = First Flysch of Pindos Zone, FSP = Flysch of Sub-Pelagonian Zone, CLP $=$ Cretaceous limestones of Pindos Zone, CLK = Cretaceous limestones of Koziaka Zone, SLSP = Cretaceous limestones of Sub-Pelagonian Zone, JSP = Jurassic limestones of Pindos Zone, JLK = Jurassic limestones of Koziaka Zone, TLP = Triassic limestones of Pindos Zone, CP = Cherts of Pindos zone, CSK = Clayey and siliceous rocks of Koziakas zone, TLCK = Limestones and cherts of Koziaka zone, SLP = Semi-crystalline limestones of Pelagonian zone, SCP = Schists and crystalline limestones of Pelagonian zone, SP = Schists of Pelagonian zone, GP = Gneisses of Pelagonian zone, $\mathrm{O}=$ Ophiolite outcrops.

ten local meteorological stations using the Thiessen polygons (polygons which define the area that is closest to each point relative to all other points) methodology (fig. 7). The intensity of rainfall was not analyzed due to lack of data.

\section{Rating of the classes of the instability factors}

Each class of the instability factors has different importance for the instigation of landslides. Hence, rating of each class based on the susceptibility of landslide was considered necessary.

The number of landslide occurrences involved in each class of the instability factors was calculated in order to establish the frequency of landslide incidences. The rating was based on the frequency dis- tribution of landslide events in each class of instability factor. This statistical analysis was used in various studies (Gupta \& Joshi, 1990; Temesgen et al., 2001) for landslide hazard evaluation using GIS.

According to the frequency of landslide events the classes of each instability factor were assigned in four discrete categories: Low, Moderate, High, and Very High. Each category corresponds to a different landslide susceptibility level.

\section{Models of the overall estimation of landslide susceptibility}

As mentioned above, the incidence of the landslides is controlled by the interaction of various factors. Since it is difficult to define the degree of this 


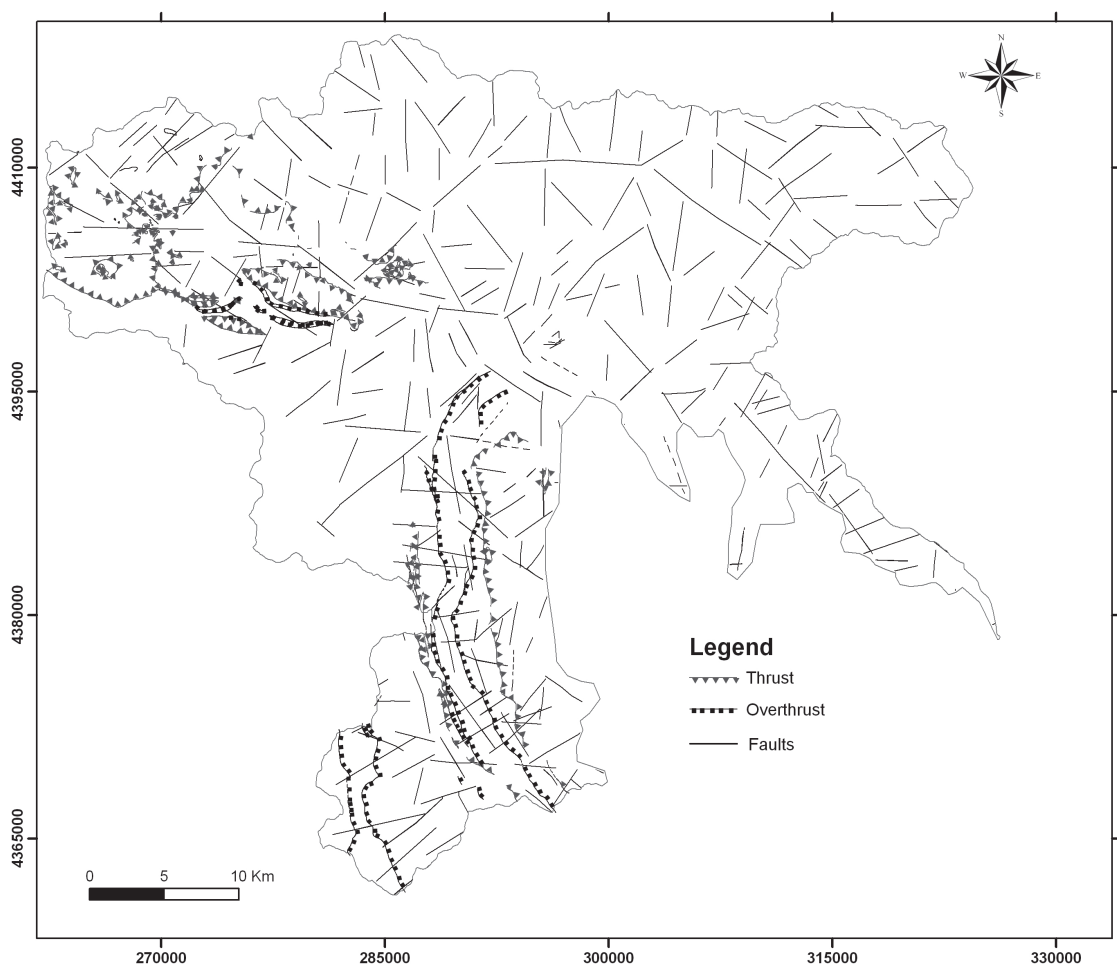

Fig. 3.-Tectonic features of the study area including thrusts, overthrusts, and faults.

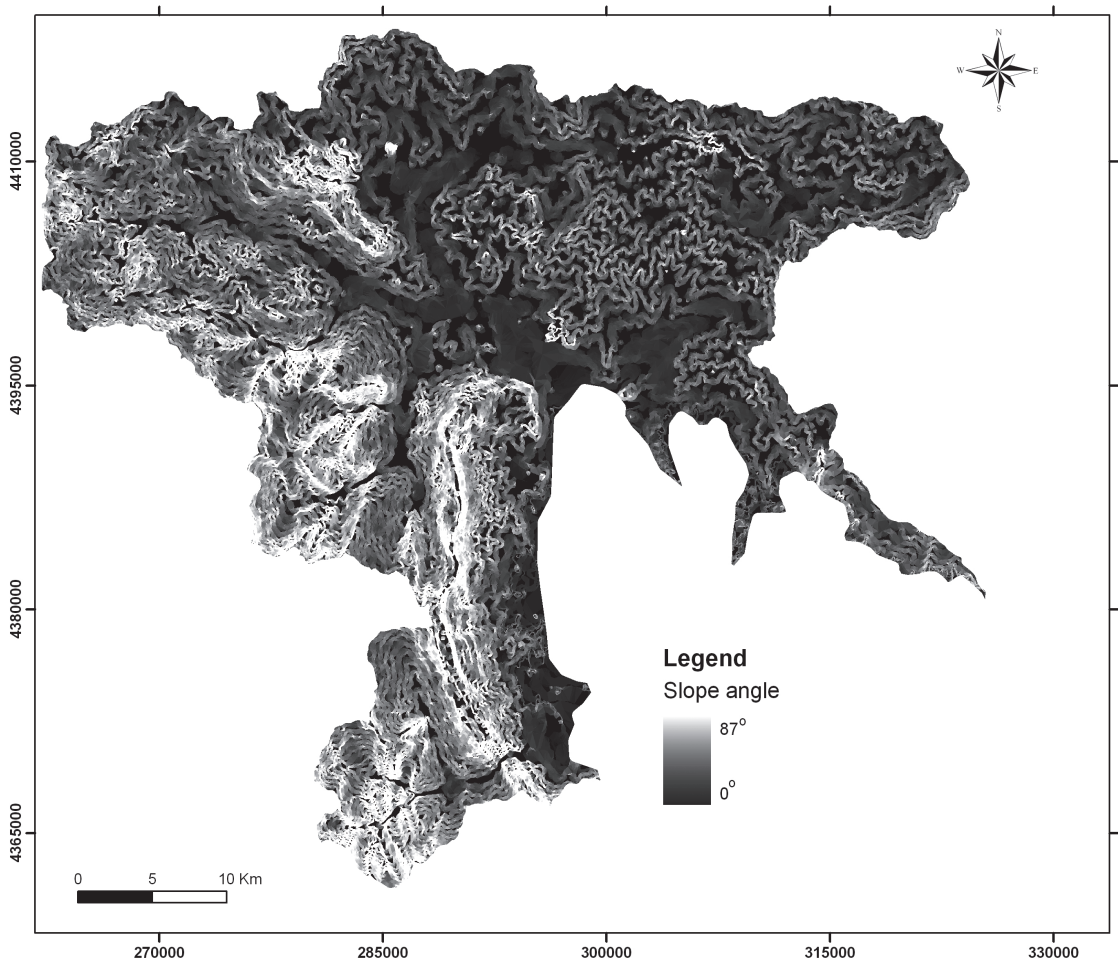

Fig. 4.-Slope angle distribution of the study area. 


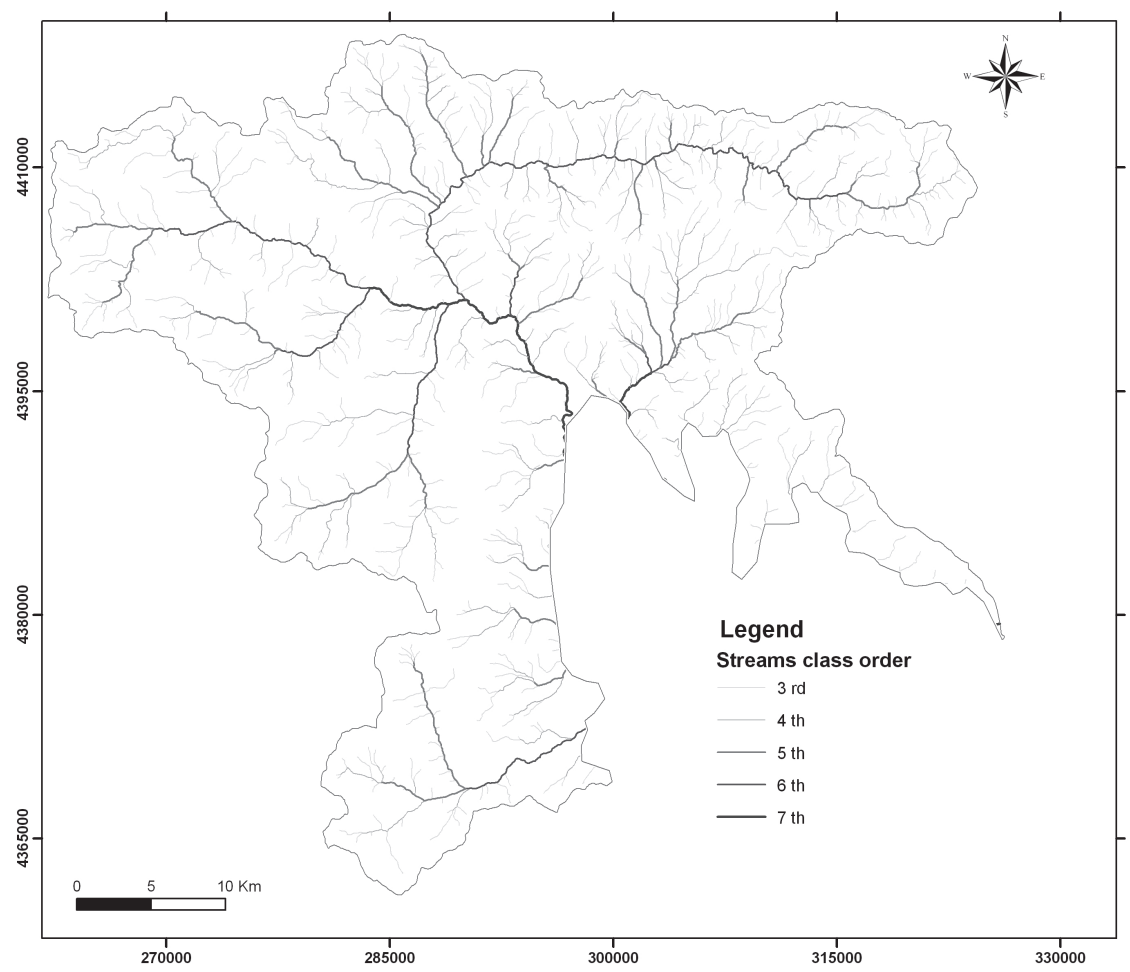

Fig. 5.-Drainage network of the study area and stream order as classified by the Strahler method.

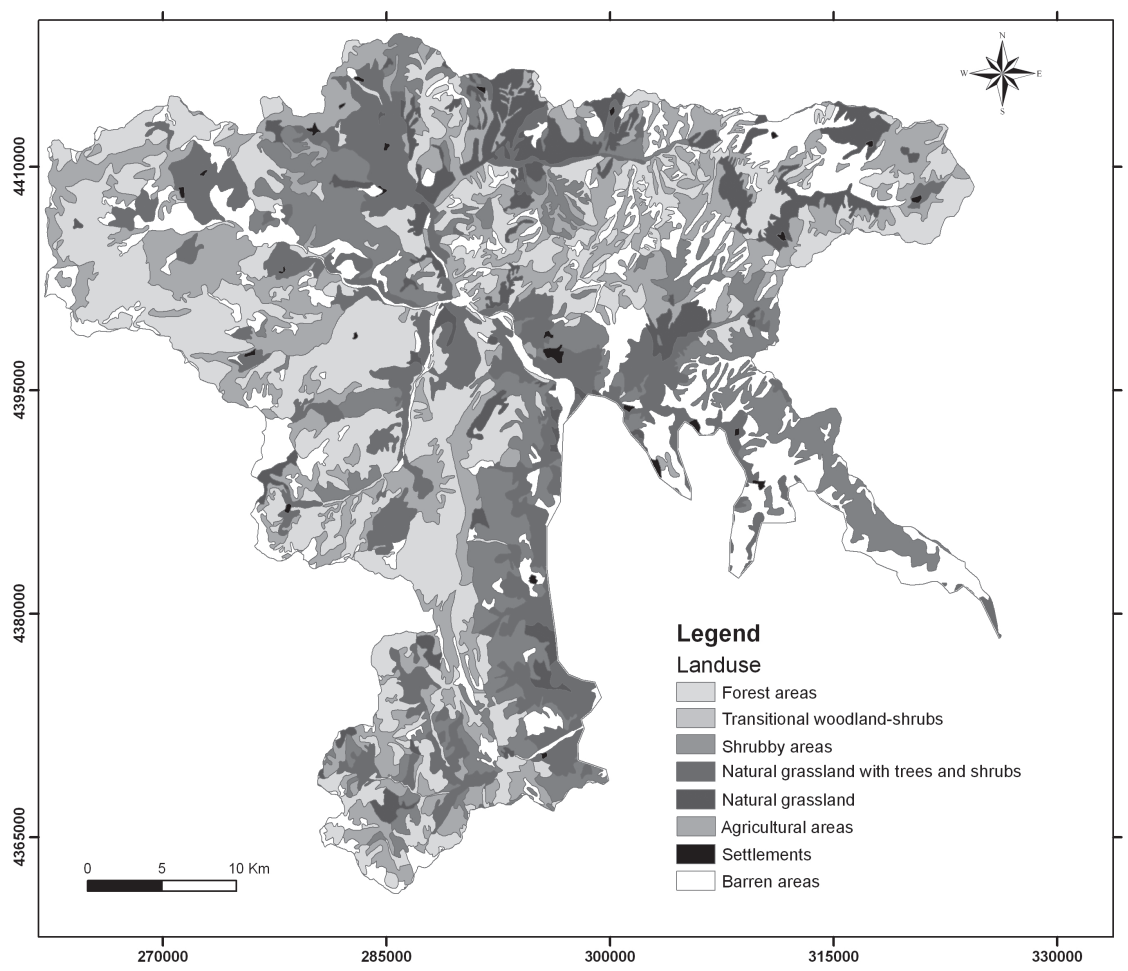

Fig. 6.-CORINE land use map. 


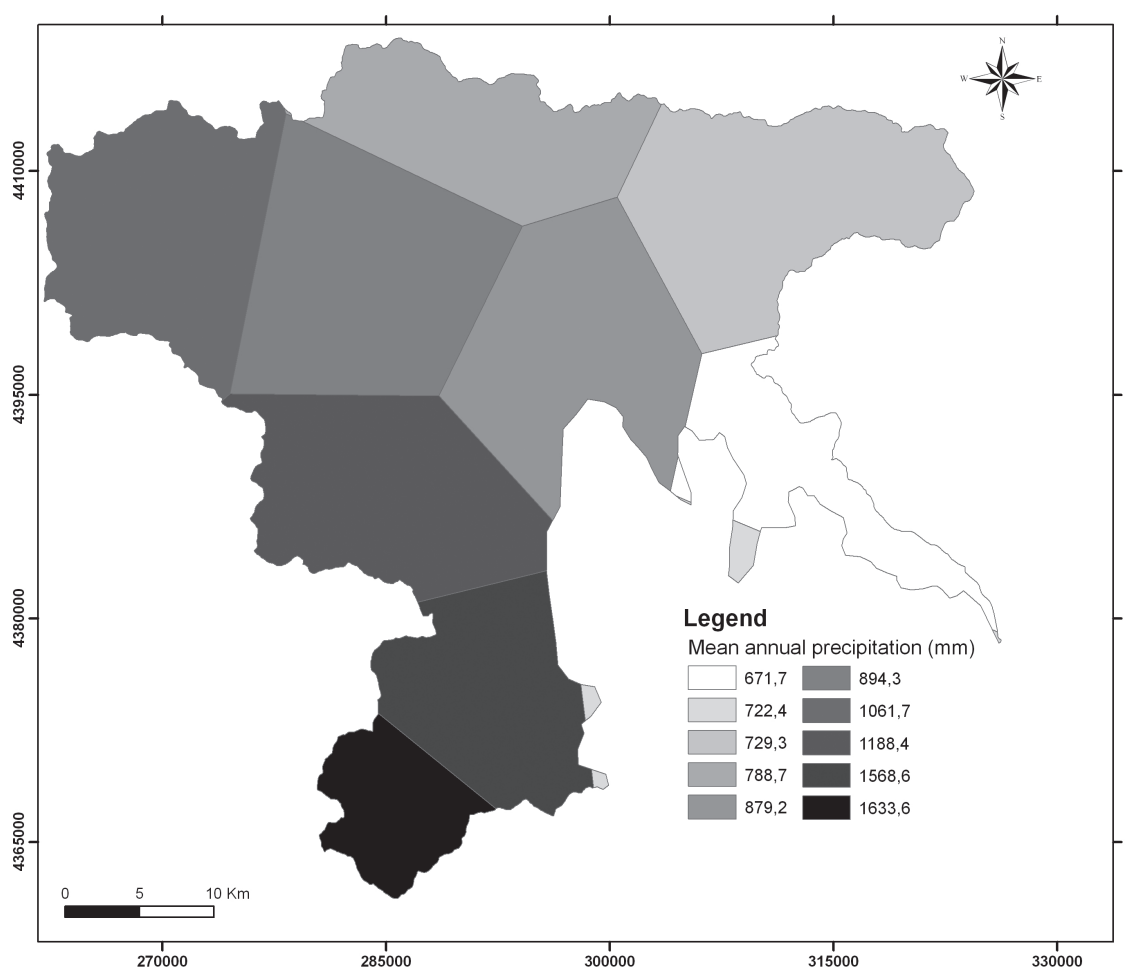

Fig. 7.-Division of the study area using the Thiessen polygons method and the mean annual precipitation.

interaction, an effort to associate the instability factors with different methods was made in this study.

Two models are used for the assessment of the overall landslide susceptibility estimation. The same instability factors and their class rating system were applied in both models. The overall estimation of the landslide susceptibility for an area results from the combination between the susceptibility levels of individual factors.

The first used model was the Weight Factor Model (WeF), which is the most common model in landslide susceptibility mapping (Wachal \& Hudak, 2000; Dai \& Lee, 2001; Lee \& Min, 2001; Temesgen et al., 2001; Saha et al., 2002; Ayalew et al., 2005). It incorporates the relative importance of each instability factor by using weights, which must be estimated.

Furthermore, during the fieldwork, it was observed that some landslides had occurred due to the simultaneous action of two or more instability factors with Very High or High susceptibility level. Therefore, a model interpreting these possible major factors was adopted, namely the Multiple Factor Model (MuF). This model was based on logical operation (and/or) that incorporates the additive influence of the higher susceptibility level of the instability factors.

\section{Results}

A total number of 608 landslides were calculated to be present in the study area. Figure 8 portrays the landslide inventory map of the study area with the two sets of landslides (training and testing set).

As it was mentioned previously the training set (including 304 landslides) was used to examine the relation of landslide occurrences with each class of instability factors and to assign their ratings.

\section{The relation of landslide occurrences with each class of instability factors}

\section{Lithology}

The lithological formations were classified upon their geotechnical characteristics (Koukis \& Rozos, 


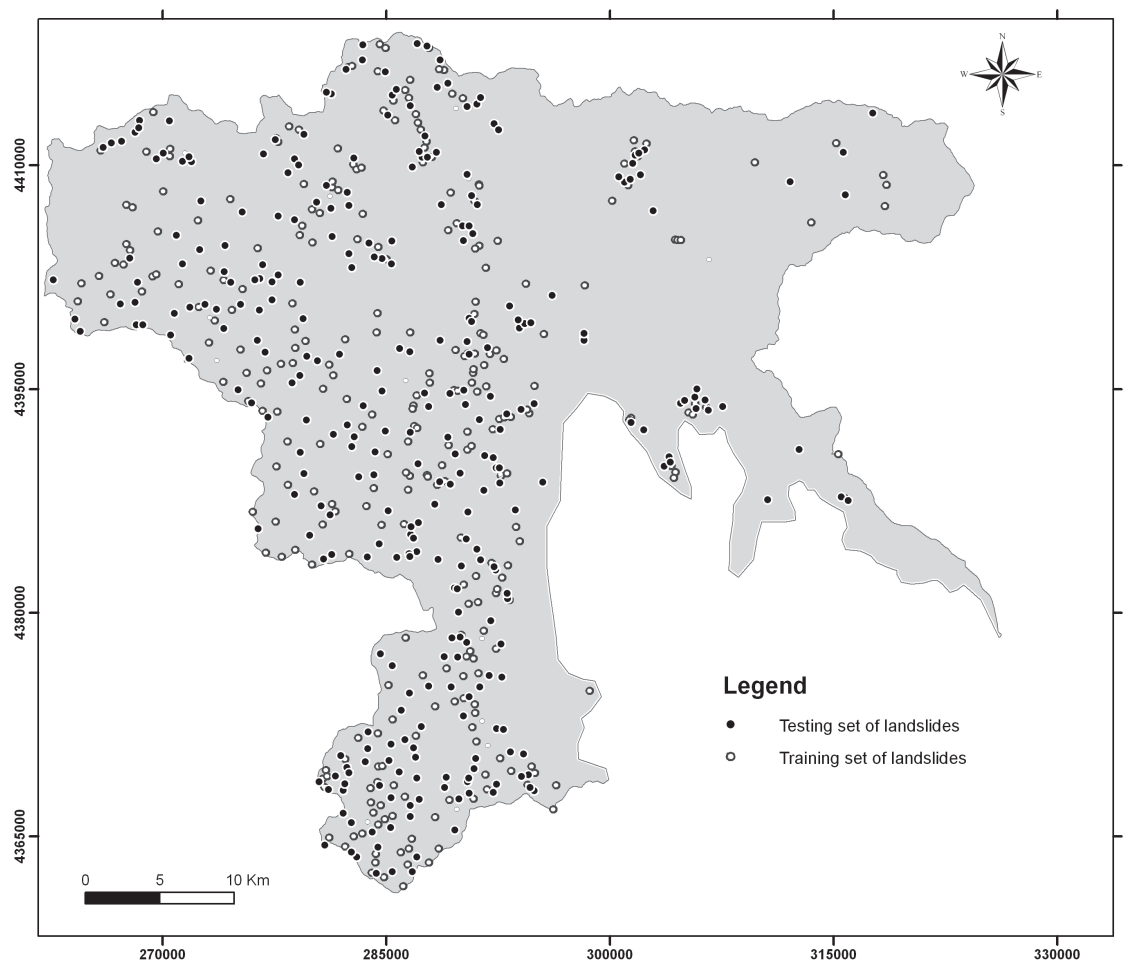

Fig. 8.-Landslide inventory map based on topographic maps, airphotos and field work; The training set includes the half of the total landslide occurrences and was used for the investigation of the relation between the landslides and the instability factors; the testing set includes the other half and was used for validation.

1982) into respective lithological groups which are the following:

- Quaternary formations (alluvial deposits — sand, clay, silt, gravels, pebbles etc.- talus cones and scree).

- Neocene sediments (terrestrial deposits).

- Molasses formations (Trikala series - marls and limestones-, Upper Meteora series - mainly conglomerates-, clastic formations of Heptachorion-Kipourion series, clastic formations of Krania series, clastic formations and limestones of Rizoma series).

- Flysch (flysch of Pindos zone, transition beds of flysch of Pindos zone, first flysch of Pindos zone, flysch of Sub-Pelagonian zone).

- Carbonate rocks (Cretaceous limestones of Pindos zone, Cretaceous limestones of Koziakas zone, Cretaceous limestones of Sub-Pelagonian zone, Jurassic limestones of Pindos zone, Jurassic limestones of Koziakas zone, Triassic limestones of Pindos zone).

- Clay-chert formation (cherts of Pindos zone, limestones and cherts of Koziaka zone, limestones and cherts of Koziaka zone).
- Metamorphic rocks (semi-crystalline limestone of Pelagonian zone, schist of Pelagonian zone, gneisses of Pelagonian zone), and

- Ophiolite outcrops.

Table 1 shows the frequency of landslide occurrences in each lithology formation and their corresponding rating. It shows that the maximum frequency of landslides events was observed in the area underlain by the flysch of the Pindos zone. The flysch formations consist of sandstones, siltstones, marls and, more rarely, grit conglomerates alternation. They are strongly folded and fractured sediments (Koukis \& Rozos 1982). The flysch sediments develop a thick zone of weathering mantle and in this zone the manifestation of landslides is frequent. Moreover during the fieldwork, high frequency of landslide events was observed in the Cretaceous limestones of the Pindos zone. These limestones are highly fractured resulting into the degradation of their geomechanical behaviour. They usually outcrop on steep slopes and this fact is in combination with the intense tectonics favour the appearance of landslide phenomena. 
Table 1.-Rating of lithological formation

\begin{tabular}{|c|c|c|}
\hline Lithological formations & $\begin{array}{c}\text { Frequency of landslide } \\
\text { occurrences }(\%)\end{array}$ & Susceptibility level \\
\hline Alluvial deposits (sand, clay, silt, gravel, pebbles, etc.) & 1.6 & Low \\
\hline Talus cones and scree & 6.9 & High \\
\hline Terrestrial deposits & 0.7 & Low \\
\hline Trikala series (marls and limestones) & 0.3 & Low \\
\hline Upper Meteora series (mainly conglomerates) & 3.6 & Moderate \\
\hline Lower Meteora series (mainly conglomerates) & 6.6 & High \\
\hline Clastic formations of Heptachorion-Kipourion series & 4.6 & Moderate \\
\hline Clastic formations of Krania series & 1.0 & Low \\
\hline Clastic formations and limestones of Rizoma series & 2.3 & Moderate \\
\hline Flysch of Pindos zone & 16.8 & Very High \\
\hline Transition beds of Flysch of Pindos zone & 0.7 & Low \\
\hline First Flysch of Pindos zone & 5.3 & High \\
\hline Flysch of Sub-Pelagonian zone & 0.3 & Low \\
\hline Cretaceous limestones of Pindos zone & 11.9 & Very High \\
\hline Cretaceous limestones of Koziaka zone & 1.0 & Low \\
\hline Cretaceous limestones of Sub-Pelagonian zone & 0.3 & Low \\
\hline Jurassic limestones of Pindos zone & 1.3 & Low \\
\hline Jurassic limestones of Koziaka zone & 9.5 & High \\
\hline Triassic limestones of Pindos zone & 0.3 & Low \\
\hline Cherts of Pindos zone & 9.8 & High \\
\hline Clayey and siliceous rocks of Koziakas zone & 3.1 & Moderate \\
\hline Limestones and cherts of Koziaka zone & 3.3 & Moderate \\
\hline Semi-crystalline limestones of Pelagonian zone & 0.3 & Low \\
\hline Schists and crystalline limestones of Pelagonian zone & 0.3 & Low \\
\hline Schists of Pelagonian zone & 0.3 & Low \\
\hline Gneisses of Pelagonian zone & 1.3 & Low \\
\hline Ophiolite outcrops & 6.6 & High \\
\hline
\end{tabular}

Hence, in these two formations a very high susceptibility level was assigned, whereas in the lithological units, such as Cretaceous limestones of Sub-Pelagonian zone, a low susceptibility level was assigned.

\section{Tectonic features}

The maximum percentage of landslide occurrences was noticed within a distance approximately $100 \mathrm{~m}$ to the tectonic features (thrusts and overthrusts, faults). As the distance from the tectonic features increases the frequency of landslide events gradually decreases (fig. 9). Consequently areas close to the tectonic features are prone to the landslides. Besides, the shear strength of the rocks near tectonic discontinuities is reduced promoting the frequency of landslides. Thus, the buffer zones were given a susceptibility level gradually decreasing with increasing distance from the tectonic features (fig. 9).

\section{Slope angle}

Slope angles were classified based on DEM in four classes: gentle slopes $\left(0-10^{\circ}\right)$, intermediate slopes $\left(10-20^{\circ}\right)$, moderately steep slopes $\left(20-30^{\circ}\right)$ and steep slopes $\left(>30^{\circ}\right)$. The frequency distribution of landslides within each class was computed and the corresponding susceptibility levels were assigned (fig. 10).

The maximum frequency of landslides was observed on steep slopes $\left(>30^{\circ}\right)$ and was followed by moderately steep slopes $\left(20-30^{\circ}\right)$. The slope failures potentially decrease with decreased gradient as shown in figure 10.

\section{Road network}

In the area under study the maximum number of landslide events (14.2\%) occurred within a distance of approximately 0 to $100 \mathrm{~m}$ from any given road (fig. 11). This may be due to the fact that the road network sometimes destabilizes adjacent marginally balanced slopes, mainly by removing natural support for the upper part of the slope through undercutting the base of the slope during its construction and by adding extra weight on them. Further away the frequency of landslide occurrences gradually decreases. Accordingly, a very high susceptibility level was 


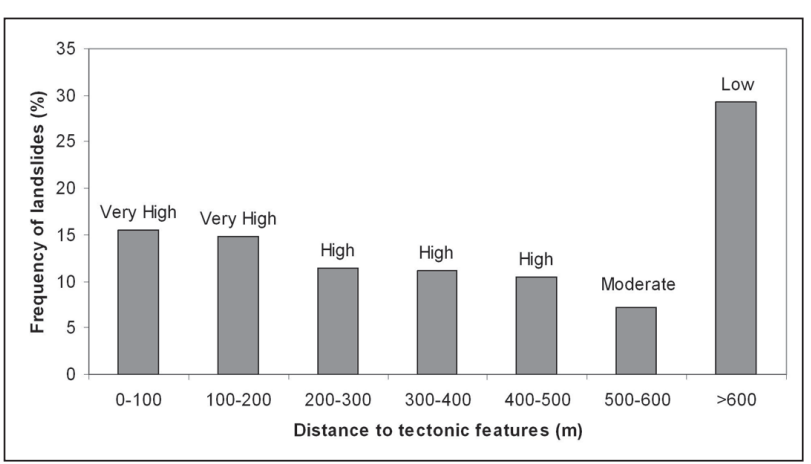

Fig. 9.-Frequency of landslide occurrences in relation with the tectonic features and susceptibility levels assigned in each distance. The frequency of landslide occurrences varies from 4.9 to $0.1 \%$ in each buffer zone of $100 \mathrm{~m}$ for the distance $600-4,500 \mathrm{~m}$ and the total is $29.3 \%$.

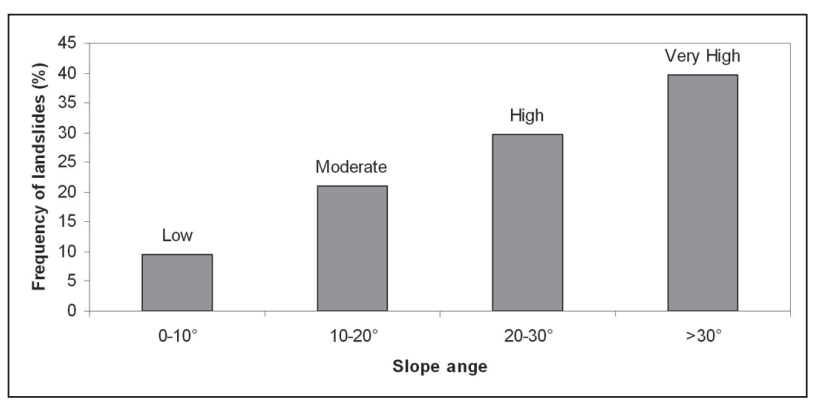

Fig. 10.-Frequency distribution of landslide occurrences within slope angles showing the maximum frequency on steep slopes. The corresponding susceptibility levels are shown in each class of slope.

given to the buffer up to a distance of $200 \mathrm{~m}$ from the road network while the low susceptibility level was assigned to distances beyond $600 \mathrm{~m}$ (fig. 11).

\section{Drainage network}

As in the cases of tectonic features and road network the frequency of landslides reaches its maximum value within the first $200 \mathrm{~m}$ of distance from any given stream (fig. 12). As the distance from the streams increases, the frequency of landslide events gradually decreases. This may be attributed to the fact that the slope undercutting from the erosion process of water is caused in areas adjacent to stream bank and often leads to landslide. Furthermore debris and soil materials close to water bodies are prone to collapse during heavy rain.

According to the frequency distribution of landslides, the highest susceptibility level was allocated to the buffers up to a distance of $200 \mathrm{~m}$ from a stream and the lowest in distances beyond $700 \mathrm{~m}$ (fig. 12).

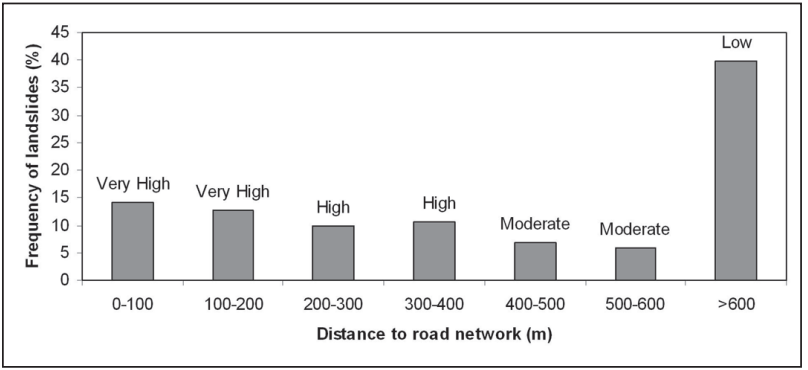

Fig. 11.-Frequency of landslide occurrences in relation with road network and the susceptibility levels which was assigned in each distance. The frequency of landslide occurrences varies from 4.6 to $0.3 \%$ in each buffer zone of $100 \mathrm{~m}$ for the distance $600-2,400 \mathrm{~m}$ and the total is $39.8 \%$.

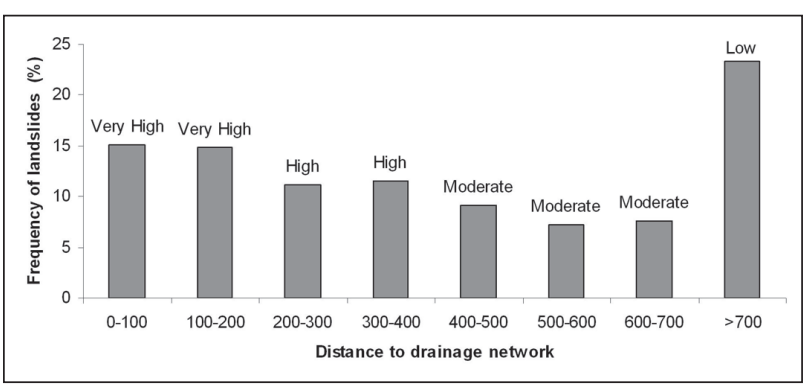

Fig. 12.-Frequency of landslide occurrences in relation with drainage network and the corresponding susceptibility levels in each distance. The frequency of landslide occurrences varies from 4.9 to $0.3 \%$ in each buffer zone of $100 \mathrm{~m}$ for the distance $700-1,900 \mathrm{~m}$ and the total is $23.4 \%$.

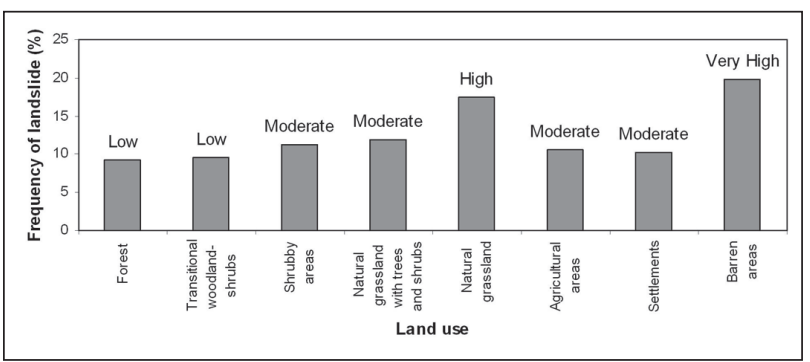

Fig. 13.-Frequency distribution of landslide occurrences in each class of land use and the estimated susceptibility levels of them are illustrated.

\section{Land use}

The frequency distribution of landslide occurrences in each class of land use and the corresponding susceptibility levels were estimated as presented in figure 13.

The barren areas are more affected by landslide activities. The frequency of landslide events is limit- 


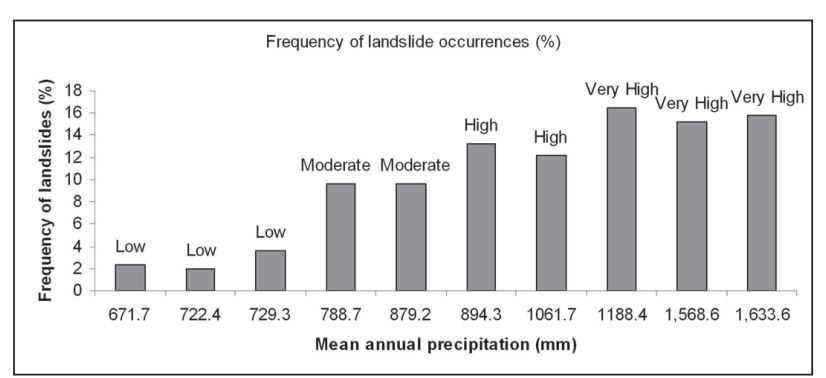

Fig. 14.-Mean annual precipitation and frequency of landslide events as well as corresponding susceptibility levels.

ed when the type of vegetation changes to grassland in shrubby areas and then to trees, while the forest areas are less frequented by landslide occurrences. The soil cohesion is modified depending on the type of vegetation and so the barren or sparsely vegetated areas are more prone to landslide processes.

\section{Rainfall}

The mean annual precipitation of the study area fluctuates from $671.7 \mathrm{~mm}$ to $1,633.6 \mathrm{~mm}$. The highest rainfall values are observed at the southwestern part of the study area and the lowest values at the eastern one. The relationship between mean annual precipitation and landslide phenomena is demonstrated in figure 14. The statistical analysis of the data showed that the frequency of landslides events increases with the increased precipitation. Therefore the rainfall is an important factor in triggering manifestation of landslide occurrences.

As a result, the highest susceptibility levels were assigned to the areas of highest annual height of rainfall (fig. 14).

\section{Landslide susceptibility mapping models}

The application of each landslide susceptibility model was performed in GIS environment using the capabilities of the Spatial Analyst extension. Some raster calculations were accomplished on the rasterized layers of the seven instability factors in order to estimate the overall landslide susceptibility. The results of the application of each model are analyzed in the following paragraphs.

\section{The Weight Factor Model (WeF)}

For the application of the WeF model, numerical values were assigned to each of the four susceptibi- lity classes of each factor as follows: Low $=1$, Moderate $=2$, High $=3$, Very High $=4$. A numerical weight is attributed for each instability factor and then an overall score (susceptibility index) is determined by the use of the following multiplicative model:

Overall susceptibility index $=a_{1} \cdot F_{1}+a_{2} \cdot F_{2}+\ldots+a_{8} \cdot F_{8}$ (1)

Where $a_{1}, a_{2}, \ldots, a_{8}$ are the numerical weights and $F_{1}, F_{2}, \ldots, F_{8}$ are the instability factors that were taken into account to the landslide susceptibility mapping.

The estimation of the numerical weights was based on the results of a logistic regression which was applied to the study area in order to describe the relationship between the presence or the absence of the landslide occurrences and the instability factors. For the calculation of the regression model $10 \%$ of the study area was used. All the landslides of the training set were included in the used sample. The calculated logistic regression model was the following:

$\mathrm{Y}=-11.363+0.343 \cdot$ lithology $+0.287 \cdot$ tectonic features $+0.114 \cdot$ slope $+0.097 \cdot$ road network + $0.261 \cdot$ drainage network $+0.023 \cdot$ land use +0.082 . rainfall.

The dependent variable $\mathrm{Y}$ expresses the absence (value 0 ) or the presence (value 1) of a landslide. The regression coefficients were used as numerical weights of the instability factors.

\section{The Multiple Factor Model (MuF)}

The MuF is a model that is based on the number of factors that are characterized as High and Very High susceptibility.

The creation of this model was based on the calculation of the number of the instability factors that had value equal to Very High, High, Moderate or Low in each cell. For example, after the combination of the instability factors, a cell had four values of Very High, one of High, one of Moderate and one of Low. This cell was considered as very prone to landslide therefore was characterized as Very High susceptibility.

Based on the possible combinations of the susceptibility levels of the seven instability factors the overall estimation of landslide susceptibility is defined using the following rules:

- Very High susceptibility: cells with more than two Very High or four High factors $(\mathrm{VH}>2$ or $\mathrm{H}>4)$. 


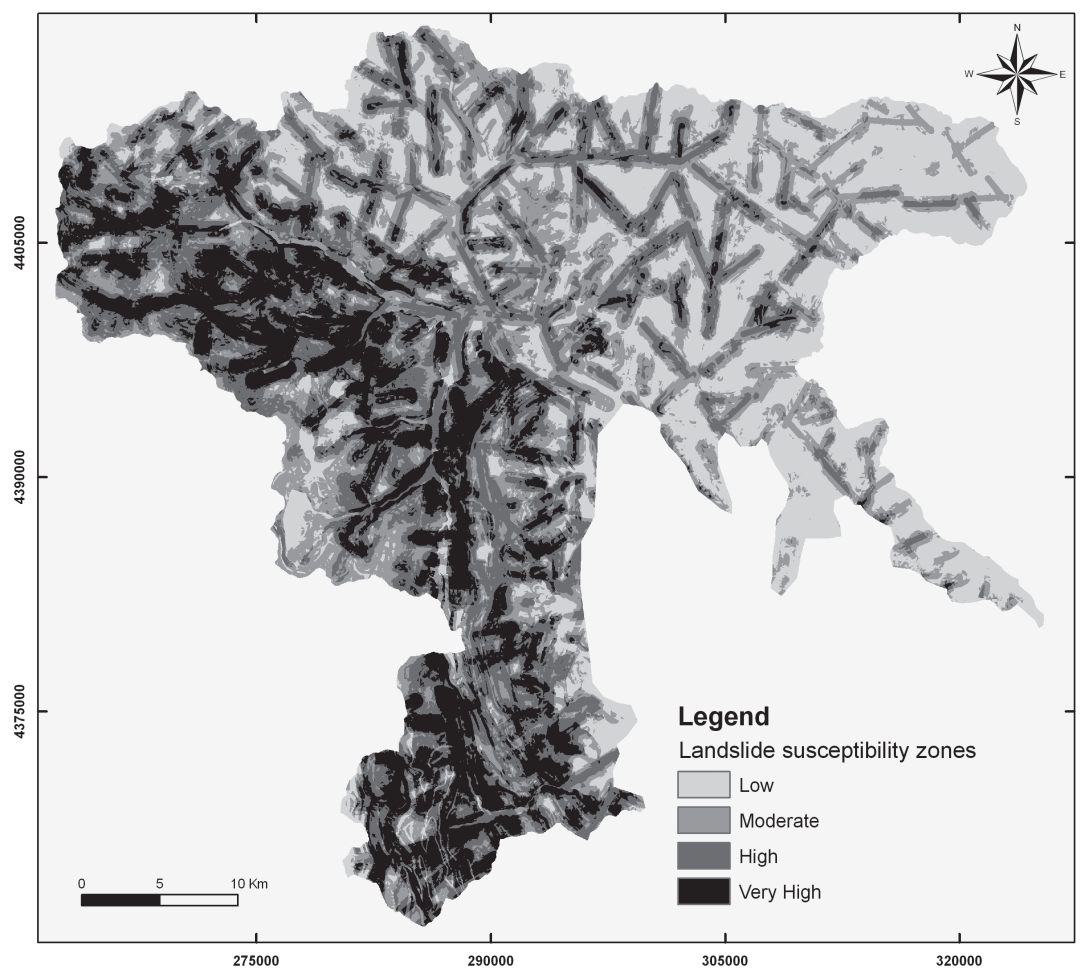

Fig. 15.-Landslide susceptibility map was produced by the Wef model. The area was classified into four zones: the Low Susceptible zone, the Moderate Susceptible zone, the High Susceptible zone, and the Very High Susceptible zone.

- High susceptibility: cells with two Very High factors or with less than two Very High and four High factors $[\mathrm{VH}=2$ or $(\mathrm{VH}<2$ and $\mathrm{H}=4)]$.

- Moderate susceptibility: cells with one Very High and more than four High factors $(\mathrm{VH}=1$ and $\mathrm{H}<4)$.

- Low susceptibility: cells with no Very High and less than four High factors $(\mathrm{VH}=0$ and $\mathrm{H}<4$ ).

From a technical perspective, it is quite easy to implement this model since it uses only logical operation and does not require firstly the estimation of weights for each instability factor and secondly the estimation of interaction synergy between different factors.

\section{The landslide susceptibility maps}

The calculations based on the above models have produced two different landslide susceptibility maps. The area of each map, in accordance with the estimated degree of landslide susceptibility, is classified into four zones: the Low Susceptible (LS), the Moderate Susceptible (MS), the High Susceptible (HS), and the Very High Susceptible (VHS) zone.

The testing set of landslide occurrences was used to validate the two landslide susceptibility maps produced from the models. The frequency of landslide occurrences laid on every susceptibility zone for each one of the two maps separately, was calculated using GIS capabilities.

The landslide susceptibility map, illustrated in figure 15, was created using the WeF model. The calculated overall susceptibility index values were categorized in four zones each one of them contains an equal number of values (quantile classification method) as follows:

$<2.00$ : Low Susceptible zone

2.00-2.49: Moderate Susceptible zone

2.50-2.90: High Susceptible zone $>$ 2.90: Very High Susceptible zone

The surface that VHS zone covers is $313.68 \mathrm{~km}^{2}$, while the HS, MS, and LS zones cover $481.53 \mathrm{~km}^{2}$, $419.22 \mathrm{~km}^{2}, 416.78 \mathrm{~km}^{2}$ correspondingly. The percentages as regards the surface of the study area, as 


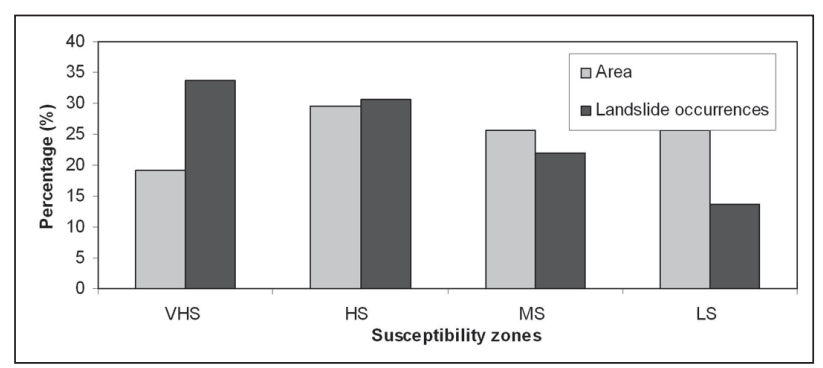

Fig. 16.-Percentages of the surface of the study area and of landslide events in each susceptibility zone as resulted from the application of the WeF model.

well as of landslide events in each susceptibility zone are shown in figure 16.

The HS zone shows the biggest area surface coverage while the surface of the VHS zone is relatively small but it includes the highest number of landslide incidences.

The VHS and HS zones have a very high frequency $(64.42 \%)$ of landslide occurrences. These two zones represent the $48.75 \%$ of the total study area.

The landslide susceptibility map demonstrated in figure 17 was produced using the MuF model. As already referred during the operation of the model the area was divided into four susceptibility zones.

The VHS zone covers $158.96 \mathrm{~km}^{2}$, while the surfaces of HS, MS, and LS zones are $466.16 \mathrm{~km}^{2}$, $578.91 \mathrm{~km}^{2}, 427.18 \mathrm{~km}^{2}$ respectively. The percentages of the area and of landslide events in each susceptibility zone are shown in figure 18 .

In the MuF model, the largest surface area is covered initially by the MS zone and secondly by the HS zone. The VHS zone covers the lowest surface percentage.

In the MuF model, the percentage of landslides, situated in the VHS zone, is smaller than the one of WeF model. The total surface area that covered by both the VHS and HS zones is $38.32 \%$ of the entire study area. Within these two zones, the landslide events correspond to $62.53 \%$.

However, both the MS and LS zones produced susceptibility maps that also include a number of landslides events. This may have occurred due to local causes such as orientation of discontinuity surfaces (trusts, faults) (Saha et al., 2002) which could not be expressed by the GIS based statistical analysis.

\section{Discussion}

The landslide susceptibility map is a useful tool in natural and urban planning, specifically for the defi- nition of the land use zones and for the design of future construction projects. In the determined LS and MS zones, it is possible to plan and construct buildings along with any economic activity. Instead, in the HS and VHS zones, extra consideration should be given in planning for any activity, including building construction. On the susceptibility zone boundaries planning must be coupled with particular studies to prevent artificial disasters and avoid their potential damages onto human lives and properties. Consequently, the more hazardous the zone is, the more specific wariness on planning is needed.

Important elements for natural and urban planning are certainly the usefulness of the landslide susceptibility models and the reliability of their outcome. Besides, it is important that the surface covered by VHS a zone is the minimum possible, whereas the number of landslide events located in this zone should be the maximum.

The evaluation of the models estimates three aspects of their applicability in planning: $a$ ) the first aspect involves the simplicity and speed of compiling and running the model, $b$ ) the second is focused on the practical part, that is the limited possible spreading of the VHS zone and $c$ ) the third one concerns the validation, in other words, the number of landslide occurrences in each zones of the models.

Although the rating method of each class of instability factors is the same for both models, the overall estimation of landslide susceptibility is different. In the MuF model the user's estimation is needed for the set up of the logical rules that are used for the identification of the overall susceptibility level based on the combination of the individual instability factors. The WeF model is based on a statistical process in order to define the weights of the instability factors. Therefore, as regard the first aspect of the models applicability in planning it was considered that the MuF model is the simplest model to set up and operate.

Regarding the practical aspect, the MuF model shows a limitation in terms of surface area of the VHS zone, even though a high proportion of landslide events are recorded in this zone (fig. 18). On the contrary, the area of VHS zone in the WeF model is more expanded while it has a similar number of landslide events with the one of the MuF model (fig. 16). For this reasons it was considered that the MuF model provides more satisfactory results from a practical point of view.

Finally, regarding the third aspect, the maximum number of landslide occurrences appears in VHS 


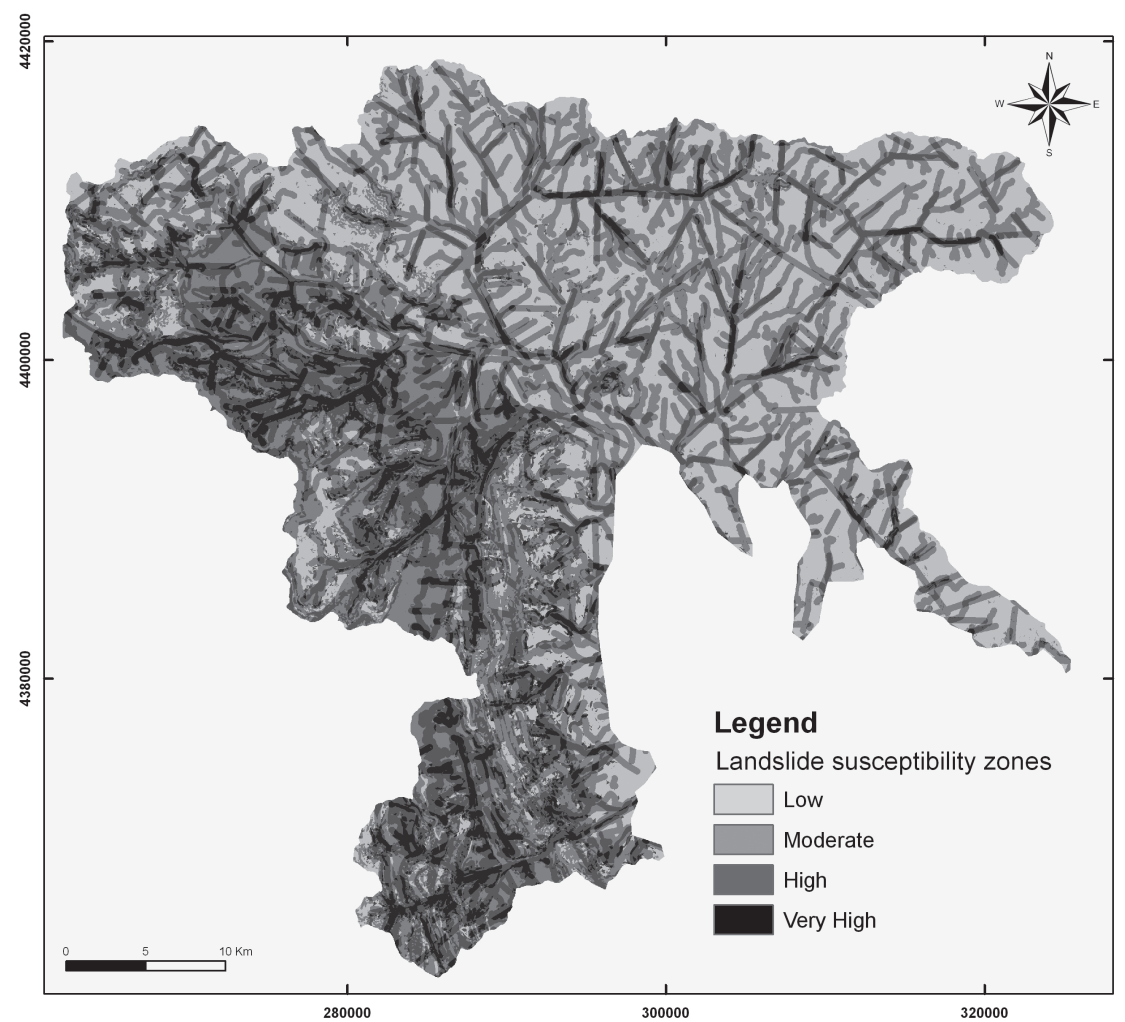

Fig. 17.-Landslide susceptibility map was produced by the MuF model. The area was classified into four zones: the Low Susceptible zone, the Moderate Susceptible zone, the High Susceptible zone, and the Very High Susceptible zone.

zones in both models. The validation process indicated the MuF model as the most reliable.

The VHS zone of each landslide susceptibility map has similar spatial distribution. More specifically, these zones are located at the western, southwestern and central part of each map (figs. 15 and 17), but their surface varies in the two different susceptibility maps.

Additionally, a quantitative evaluation of the $\mathrm{MuF}$ and WeF models was made. For this purpose an indicator, namely the Landslide Models Indicator (La.M.I.) was created. The La.M.I. relates the percentage of the landslide occurrences located in a susceptibility zone to the area of the specific susceptibility zone as percentage of the entire study area. The simple mathematical formula for calculating the La.M.I. is as follows:

La.M.I. $=\mathrm{N}_{\mathrm{L}} / \mathrm{S}_{\mathrm{HZ}}$

where $\mathrm{N}_{\mathrm{L}}$ is the percentage of the frequency of landslide events in a susceptibility zone and the $\mathrm{S}_{\mathrm{HZ}}$ is the percentage of the area of the same susceptibility zone as regards the total study area. When the

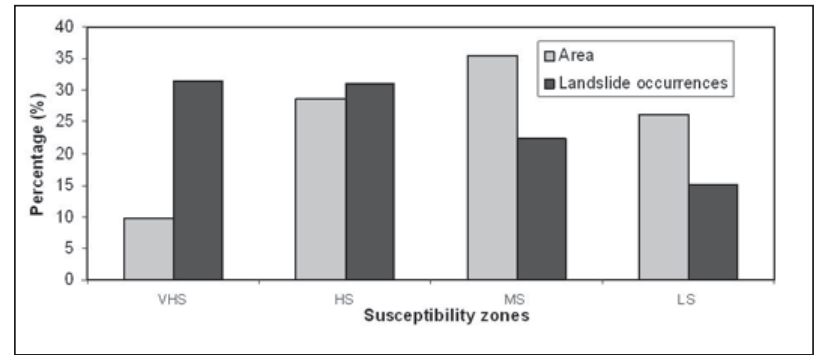

Fig. 18.-Percentages of the surface of the study area and of landslide events in each susceptibility zone as resulted from the application of the MuF model.

La.M.I., reaches a maximum value in a specific susceptibility zone it is expected that the model provides better results for this zone. This means that in a given zone with small area we have the highest percentage of landslides events within, when a model is operating.

The results of the La.M.I application shown in figure 19 point that the best value for the VHS and HS zones is derived for the MuF model. It must be noted that the La.M.I. was not applied to the MS 


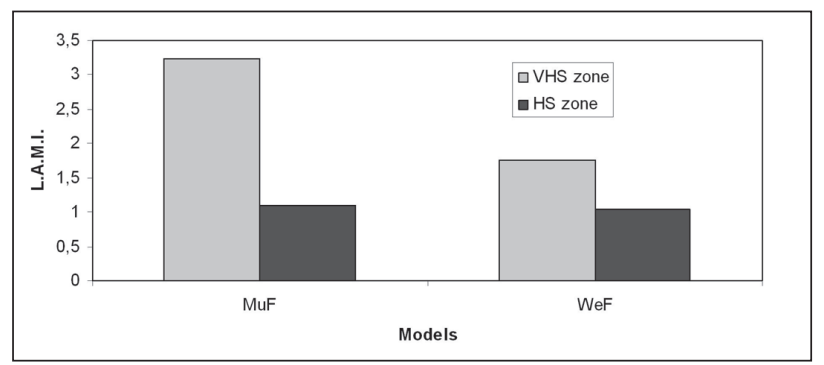

Fig. 19.-Results of La.M.I demonstrating that the maximum for the VHS and HS zones results from the MuF model.

and LS zones because in terms of planning, it is either the VHS or the HS zones that matter mostly.

The La.M.I. acts as a guide to the selection of the best model to estimate the landslide phenomena and may turn to be a useful tool in natural and urban planning depending on land use or the building activities and other construction required.

It is worth mentioning that only the mountainous terrains have been included to the study area, whereas, the southern and southeastern flat land zone, that is not susceptible to landsliding, has been omitted. However, in doing so though, i.e. in case that the flat zone was included to the research, this flat zone should have to be incorporated in the LS or the MS zone. Hence, the percentage of the zones with low or moderate landslide susceptibility would be potentially increased. This result is much more valuable in land use planning and decision of administrative division (e.g. prefecture, municipality) because in that case the whole region is taken into consideration.

\section{Conclusions}

The landslide susceptibility map is necessary for the definition of the land use zones and for the design of future construction projects. Numerous models have been applied for landslide susceptibility mapping. An effort was made in this study to produce landslide susceptibility maps using different methods and then evaluate their results.

The application of the GIS techniques supported the design and operation of two different methods: the Weight Factor Model (WeF) which is a statistical model and the Multiple Factor Model (MuF) whose compilation was made by simple logical operations.

It was observed that the MuF model is easier to set up and operate than the WeF model. Likewise this model produces a smaller area of VHS zone as compared to the generated one of WeF model while the frequency of landslides within the VHS zones of each model was similar. Thus it was considered that the MuF model provides more satisfactory and reliable results.

Finally, the quantitative evaluation of the models' results was supplemented by the use of a Landslide Models Indicator (La.M.I.), associating the frequency of landslides laid in a susceptibility zone with the surface of this zone. According to La.M.I, the best result for the VHS and HS zones is provided by the MuF model.

\section{References}

Anbalagan, R. (1992). Landslide hazard evaluation and zonation mapping in mountainous terrain. Engineering Geology, 32: 269-277.

doi:10.1016/0013-7952(92)90053-2

Ayalew, L. \& Yamagishi, H. (2005). The application of GIS-based logistic regression for landslide susceptibility mapping in the Kakuda-Yahiko Mountains, Central Japan. Geomorphology, 65: 15-31. doi:10.1016/j.geomorph.2004.06.010

Ayalew, L.; Yamagishi, H.; Marui, H. \& Kanno, T. (2005). Landslides in Sado Island of Japan: Part II. GIS-based susceptibility mapping with comparisons of results from two methods and verifications. Engineering Geology, 81: 432-445.

doi:10.1016/j.enggeo.2005.08.004

Bathrellos, G. (2005). Geological, geomorphological and geographic study of urban areas in Trikala PrefectureWestern Thessal. Ph.D thesis, National and Kapodistrian University of Athens, Athens, Greece, $561 \mathrm{pp}$.

Bossard, M.; Feranec, J. \& Otahel, J. (2000). CORINE land cover technical guide-Addendum 2000. European Environment Agency, Copenhagen, 104 pp.

Carrara, A.; Guzzetti, F.; Cardinali, M. \& Reichenbach, P. (1999). Use of GIS technology in the prediction and monitoring of landslide hazard. Natural Hazards, 20: 117-135. doi:10.1023/A:1008097111310

Carrara, A.; Giovanni, C. \& Frattini, P. (2003). Geomorphological and historical data in assessing landslide hazard. Earth Surface Processes and Landforms, 28: 1125-1142. doi:10.1002/esp.545

Chau, K.T.; Sze, Y.L.; Fung, M.K.; Wong, W.Y.; Fong, E.L. \& Chan, L.C.P. (2004). Landslide hazard analysis for Hong Kong using landslide inventory and GIS. Computers \& Geosciences, 30: 429-443. doi:10.1016/j.cageo.2003.08.013

Dai, F.C. \& Lee, C.F. (2001). Frequency-volume relation and prediction of rainfall-induced landslides. Engineering Geology, 59: 253-266. doi:10.1016/S0013-7952(00)00077-6

Dai, F.C.; Lee, C.F. \& Ngai, Y.Y. (2002). Landslide risk assessment and management: an overview. Engineering Geology, 64: 65-87.

doi:10.1016/S0013-7952(01)00093-X 
Donati, L. \& Turrini, M. C. (2002). An objective method to rank the importance of the factors predisposing to landslides with the GIS methodology: application to an area of the Apennines (Valnerina; Perugia, Italy). Engineering Geology, 63: 277-289. doi:10.1016/S0013-7952(01)00087-4

Duman, T.; Çan, T.; Emre, Ö.; Keçer, M.; Dogan, A.; Ates, S. \& Durmaz, S. (2005). Landslide inventory of southwestern Anatolia, Turkey. Engineering Geology, 77: 99-114.doi:10.1016/j.enggeo.2004.08.005

Gritzner, M.L.; Marcus, W.A.; Aspinall, R. \& Custer, S.G. (2001). Assessing landslide potential using GIS, soil wetness modeling and topographic attributes, Payette River, Idaho. Geomorphology, 37: 149-165. doi:10.1016/S0169-555X(00)00068-4

Gupta, R.P. \& Joshi, B.C. (1990). Landslide hazard zoning using the GIS approach- a case study from the Ramganga catchment, Himalayas. Engineering Geology, 28: 119-131. doi:10.1016/0013-7952(90)90037-2

Guthrie, R.H. \& Evans, S.G. (2004). Analysis of landslide frequencies and characteristics in a natural system, coastal British Columbia. Earth Surface Processes and Landforms, 29: 1321-1339. doi:10.1002/esp.1095

Guzzetti, F.; Carrara, A.; Cardinali, M. \& Reichenbach, P. (1999). Landslide hazard evaluation: a review of current techniques and their application in a multi-scale study, Central Italy. Geomorphology 31: 181-216. doi:10.1016/S0169-555X(99)00078-1

Koukis, G. \& Rozos, D. (1982). Geotechnical conditions and landslide movements in the Greek territory in relation to the geological structure and geotectonic evolution. Mineral Wealth, 16: 53-69.

Koukis, G.; Rozos, D. \& Hadzinakos, I. (1997). Relationship between rainfall and landslides in the formations of Achaia County, Greece. Proceedings of International Symposium on Engineering Geology and the Environment, 1: 793 -798.

Lan, H.X.; Zhou, C.H.; Wang, L.J.; Zhang, H.Y. \& Li, R.H. (2004). Landslide hazard spatial analysis and prediction using GIS in the Xiaojiang watershed, Yunnan, China. Engineering Geology, 76: 109-128. doi:10.1016/j.enggeo.2004.06.009

Larsen, M.C. \& Parks, J.E. (1997). How wide is a road? The association of roads and mass movements in a forested montane environment. Earth Surface Processes and Landforms, 22: 835-848.

doi:10.1002/(SICI)1096-9837(199709)22:9<835::AIDESP782>3.0.CO;2-C

Lee, S. \& Min, K. (2001). Statistical analysis of landslide susceptibility at Yongin, Korea. Environmental Geology, 40: 1095-1113. doi:10.1007/s002540100310

Lee, S. \& Sambath, T. (2006). Landslide susceptibility mapping in the Dammrei Romel area, Cambodia using frequency ratio and logistic regression models. Environmental Geology, 50: 846-855. doi:10.1007/s00254-006-0256-7

Lekkas, E. (2000). Natural and technological disasters destructions. Access Pre-press: Athens (in Greek) 278 pp.

Liu, J.G.; Mason, P.J, Clerici N.; Chen, S.A.; Davis, A.; Miao, F.; Deng, H. \& Liang, L. (2004). Landslide haz- ard assessment in the Three Gorges area of the Yangtze River using ASTER imagery: Zigui-Badong. Geomorphology, 61: 171-187.

doi:10.1016/j.geomorph.2003.12.004

Moreiras, S.M. (2005). Landslide susceptibility zonation in Rio Mendoza Valley, Argentina. Geomorphology, 66: 345-357. doi:10.1016/j.geomorph.2004.09.019

Nagarajan, R.; Mukherjee, A.; Roy, A. \& Khire, M.V. (1998). Temporal remote sensing data and GIS application in landslide hazard zonation of part of Western Ghat, India. International Journal of Remote Sensing, 19: 573-585. doi:10.1080/014311698215865

Parise, M. (2001). Landslide mapping techniques and their use in the assessment of the landslide hazard. Physics and Chemistry of the Earth, 26: 697-703. doi:10.1016/S1464-1917(01)00069-1

Remondo, J.; Soto, J.; González-Díez, A.; Terán J.R.D., \& Cendrero A. (2005). Human impact on geomorphic processes and hazards in mountain areas in northern Spain. Geomorphology, 66: 69-84.

doi:10.1016/j.geomorph.2004.09.009

Rozos, D.; Hadzinakos, I. \& Nicolaou N.S. (1988). Landslides inventory and classification of the mountainous road network of the Karditsa county. Bulletin of Geological Society of Greece, 23: 95-109.

Saha, A.K.; Gupta, R.P. \& Arora, M.K. (2002). GISbased Landslide Hazard Zonation in the Bhagirathi (Ganga) Valley, Himalayas. International Journal of Remote Sensing, 23: 357-369. doi:10.1080/01431160010014260

Shaban, A.; Khawlie, M.; Bou Kheir, R. \& Abdallah, C. (2001). Assessment of road instability along a typical mountainous road using GIS and aerial photos, Lebanon, Eastern Mediterranean. Bulletin of Engineering Geology and Environment, 60: 93-101. doi:10.1007/s100640000092

Temesgen, B.; Mohammed, M.U. \& Korme, T. (2001). Natural Hazard Assessment Using GIS and Remote Sensing Methods, with Particular Reference to the Landslides in the Wondogenet Area, Ethiopia. Physics and Chemistry of the Earth, 26: 665-675. doi:10.1016/S1464-1917(01)00065-4

Wachal, D.J \& Hudak, P.F. (2000). Mapping landslide susceptibility in Travis County, Texas, USA. GeoJournal, 51: 245-253. doi:10.1023/A:1017524604463

van Westen, C.J.; Seijmonsbergen, A.C. \& Mantovani, F. (1999). Comparing landslide Hazard maps. Natural Hazards, 20: 137-158. doi:10.1023/A:1008036810401

Zêzere, J.L.; De Brum Ferreira, A. \& Rodrigues, M.L. (1999). The role of conditioning and triggering factors in the occurrence of landslides: a case study in the area north of Lisbon Portugal. Geomorphology, 30: 133-146. doi:10.1016/S0169-555X(99)00050-1

Ziourkas, C. \& Koukis, G. (1992). Landslides hazard zonation in the Greek territory and its presentation in maps of small and middle scale. Mineral Wealth, 77: 9-30.

Recibido el 21 de diciembre de 2007 Aceptado el 9 de octubre de 2008 Publicado online el 27 de noviembre de 2008 